\title{
KARAKTERISTIK EKSOPOLISAKARIDA MIKROALGA Porphyridium cruentum YANG BERPOTENSI UNTUK PRODUKSI BIOETANOL
}

\author{
Alwahidul Mubarok* ${ }^{\star}$ Iriani Setyaningsih, Uju \\ Departemen Teknologi Hasil Perairan, Fakultas Perikanan dan Ilmu Kelautan, \\ Institut Pertanian Bogor, Kampus IPB Darmaga, Jalan Agatis, Bogor 16680 \\ Telepon (0251) 8622915 Faks.(0251) 8622916 \\ *Korespondensi: aal.surplus@gmail.com \\ Diterima: 28 Desember 2017/ Disetujui: 21 Maret 2018
}

Cara sitasi: Mubarok A, Setyaningsih I, Uju. 2018. Karakteristik eksopolisakarida mikroalga Porphiridium cruentum yang berpotensi untuk produksi bioetanol. Jurnal Pengolahan Hasil Perikanan Indonesia. 21(1): 24-34.

\section{Abstrak}

Porphyridium cruentum merupakan salah satu mikroalga yang memiliki kandungan polisakarida yang tinggi dan mampu menghasilkan polisakarida ekstraseluler dengan jumlah mencapai 19,7 g/L. Mikroalga tidak mengandung lignin sebagai pelindung dinding selnya, sehinggaberpotensi sebagai bahan produksi bioetanol. Kendala yang dihadapi untuk mendapatkan eksopolisakarida $P$. cruentum yaitu pada tahap pemanenan, pemisahan eksopolisakarida dari media kultivasi. Tujuan penelitian ini adalah membandingkan metode pemanenan eksopolisakarida $P$. cruentum dengan bahan presipitasi yang berbeda untuk mendapatkan metode alternatif yang lebih baik, serta menentukan metode hidrolisis terbaik untuk menghasilkan gula tertinggi. Penelitian dilakukan dengan tiga tahap terdiri dari kultivasi mikroalga, pemanenan dan karakterisasi eksopolisakarida, serta hidrolisis eksopolisakarida. Metode kultur menggunakan perlakuan fotoperiod 12 jam gelap 12 jam terang. Kultur P. Cruentum dipresipitasi dengan etanol 96\% perbandingan 1:0,75 (v/v) dan $\mathrm{KOH} 5 \%$ perbandingan 1:1,5 (v/v). Polisakarida dihidrolisis dengan $\mathrm{HCl} 2 \mathrm{~N}$ dan akuades (suhu $100^{\circ} \mathrm{C}$, selama 3 jam). Hasil penelitian menunjukkan bahwa kadar air eksopolisakarida presipitasi dengan etanol $96 \%$ yaitu $12,70 \%$, abu $59,68 \%$, viskositas $76,8 \mathrm{Cp}$, rendemen 1,4 g/L dan eksopolisakarida hasil presipitasi dengan $\mathrm{KOH} \mathrm{5 \%} \mathrm{dengan} \mathrm{kadar} \mathrm{air} \mathrm{5,28 \% ,} \mathrm{abu} \mathrm{78,61 \%} \mathrm{viskositas}$ $134,4 \mathrm{cP}$, rendemen $6,1 \mathrm{~g} / \mathrm{L}$. Monosakarida yang terdeteksi adalah fruktosa. Hidrolisis menggunakan $\mathrm{HCl}$ $2 \mathrm{~N}$, suhu $100^{\circ} \mathrm{C}$ selama 3 hari merupakan metode hidrolisis eksopolisakarida terbaik dengan kadar gula total tertinggi yaitu $24,31 \%$

Kata kunci : bioetanol, eksopolisakarida, hidrolisis asam, Porphyridium cruentum

\section{Characterization of Exopolysaccharide from Microalgae Porphyridium cruentum which has Potential for Bioethanol Feedstock}

\begin{abstract}
Porphyridium cruentum is one of the single cell microalgae which has high polysaccharide content and it can produce extracellular polysaccharides up to $19,7 \mathrm{~g} / \mathrm{L}$. Microalgae has no lignin covering of its cell wall, therefore it is potential as a bioethanol feedstock. The obstacle to obtain an exopolysaccharides from P.cruentum is harvesting stage,separating exopolysaccharides from culturing media. The purposes of this study were to compare harvesting of P.cruentum exopolysaccharide using different precipitant, to obtain the best precipitant, and to determine the best acid hydrolysis method to produce the highest sugar. This research was conducted in three stages, microalgae cultivation; harvesting and characterization of exopolysaccharides; and acid hydrolysis of exopolysaccharides. The cultivation method was carried out using photoperiod treatment 12 hours dark 12 hours light. P. cruentum exopolysaccharide was harvested by precipitation using $96 \%$ ethanol with a ratio of $1: 0,75 \mathrm{v} / \mathrm{v}$ and $5 \% \mathrm{KOH}$ with a ratio of $1: 1,5 \mathrm{v} / \mathrm{v}$. The xopolysaccharide was hydrolyzed with $2 \mathrm{~N}$ of $\mathrm{HCl}$ or distillated water (temperature $100^{\circ} \mathrm{C}$, for 3 hours). Precipitated exopolysaccharide using ethanol $96 \%$ and $\mathrm{KOH} 5 \%$ contained moisture of $12,70 \%$ and 5,28\%; ash of $59,68 \%$ and $78,61 \%$; viscosity of 76,8 and $134,4 \mathrm{cP}$, respectively. Monosaccharide detected was fructose. The exopolysaccharide yield precipitated with $\mathrm{KOH} 5 \%(6,1 \mathrm{~g} / \mathrm{L})$ was higher than that of ethanol $96 \%(1,4 \mathrm{~g} / \mathrm{L})$. Hydrolysis using $\mathrm{HCl} 2 \mathrm{~N}\left(100^{\circ} \mathrm{C}\right.$, for 3 hours) was the best method with total sugar content was $24,31 \%$.
\end{abstract}




\section{PENDAHULUAN}

Mikroalga menjadi salah satu jenis bahan yang sangat potensial digunakan sebagai bioetanol, karena memiliki kemampuan untuk tumbuh dalam waktu yang relatif singkat, bisa dikembangbiakkan pada area yang terbatas, serta beberapa jenis mikroalga memiliki kandungan karbohidrat yang tinggi. Spolaore et al. (2006) menyatakan bahwa biomasa kering Porphyridium cruentum mengandung karbohidrat sebanyak 40-57\%. Porphyridium cruentum juga menghasilkan polisakarida ekstraseluler hingga 19,7 g/L (Kusmiati dan Agustini 2009). Patel et al. (2013) melaporkan bahwa polisakarida ekstraseluler $P$. cruentum mengandung empat monosakarida yaitu galaktosa $40 \%$, xilosa $30 \%$, glukosa $20 \%$, dan asam glukoronik sebesar $10 \%$.

Bioetanol memiliki kegunaan yang cukup luas di bidang farmasi hingga bahan bakar, oleh sebab itu bioetanol memiliki nilai guna yang sangat penting. Ketersediaan bioetanol saat ini belum optimal, terlebih untuk kebutuhan bahan bakar yang masih menggunakan sumber daya yang tidak dapat diperbaharui. Hal ini mengkhawatirkan, karena renstra Kementerian ESDM tahun 2015-2019 melaporkan bahwa bahan-bahan tersebut akan habis pada kurun waktu 10 hingga 20 tahun lagi (KESDM 2015).

Sumber-sumber baru terus dicari dan dikembangkan guna menghasilkan bioetanol dari bahan-bahan alternatif yang mengandung karbohidrat, di antaranya bahan-bahan yang mengandung gula atau pati dan biomasa. Kebutuhan pangan yang tinggi, menjadikan bahan-bahan bergula atau berpati lebih diutamakan untuk kebutuhan pangan dari pada kebutuhan bahan bakar. Kendala yang dihadapi dalam penggunaan biomasa sebagai bahan untuk produksi bioetanol adalah biaya yang tinggi pada proses penghilangan lignin yang menjadi penghalang untuk hidrolisis dan fermentasi. Porphyridium cruentum berpotensi sebagai sumber alternatif karena tidak mengandung lignin. Arad dan Levy-Ontman (2010) menyatakan bahwa $P$. cruentum merupakan salah satu mikroalga merah bersel tunggal yang tidak memiliki komponen selulosa mikrofibril, namun dinding selnya dibungkus dengan polisakarida sulfat yang membentuk gel, serta memiliki polisakarida ekstraseluler yang mudah diekstrak.

Kendala yang dihadapi untuk mendapatkan eksopolisakarida $P$. cruentum yaitu pemisahan eksopolisakarida dari media. Pemisahan eksopolisakarida dari $P$. cruentum dapat dilakukan dengan menggunakan etanol (Patel et al. 2013; Setyaningsih et al. 2013). Metode ini kurang efisien bila digunakan untuk produksi masal, karena biaya yang tinggi, sehingga perlu dicari bahan alternatif. Bahan yang bisa digunakan untuk memisahkan eksopolisakarida dari kultur antara lain menggunakan alkali, salah satunya $\mathrm{KOH}$. Prasetyo et al. (2016) melaporkan bahwa $\mathrm{KOH}$ bisa digunakan untuk memisahkan eksopolisakarida.

Produksi bioetanol menggunakan eksopolisakarida $P$. cruentum belum pernah dilakukan, oleh karena itu perlu dilakukan kajian awal mengenai karakteristik eksopolisakarida P. cruentum yang dipresipitasi dengan presipitan berbeda sebagai bahan untuk produksi bioetanol. Tujuan dari penelitian ini adalah membandingkan penggunaan bahan presipitasi yang berbeda pada pemanenan eksopolisakarida $P$. cruentum untuk ditentukan karakteristik masing-masing, serta menentukan metode hidrolisis asam terbaik untuk menghasilkan gula tertinggi sebagai bahan baku produksi bioetanol.

\section{BAHAN DAN METODE Bahan dan Alat}

Bahan-bahan yang digunakan dalam penelitian adalah mikroalga $P$. cruentum koleksi kultur Pusat Penelitian dan Pengembangan Oseanografi LIPI Ancol dan ditumbuhkan di Laboratorium Bioteknologi Hasil Perairan Departemen THP Institut Pertanian Bogor. Bahan-bahan kimia yang digunakan dalam pembuatan media kultivasi adalah media modifikasi Guilard F/2 yang terdiri atas $\mathrm{NaNO}_{3}$ (Merck), $\mathrm{Na}_{2} \mathrm{HPO}_{4}$ (Merck), $\quad \mathrm{FeCl}_{2}$ (Merck), $\mathrm{Na}$ (II)-EDTA (Merck), $\mathrm{CuSO}_{4}$ (Merck), $\mathrm{ZnSO}_{4}$ (Merck), $\mathrm{NaMoO}_{4}$ (Merck), $\mathrm{CoCl}_{2}$ (Merck), $\mathrm{MnCl}_{2}$ (Merck) dan Vitamin B komplek Neurobion 
5.000 (Merck), masing-masing bahan dilarutkan pada $100 \mathrm{~mL}$ akuades. Bahan kimia lain yang digunakan adalah etanol 96\% (Merck), $\mathrm{NaOH} 2 \mathrm{~N}$ (Merck), $\mathrm{HCl} 2 \mathrm{~N}$ (Merck), KOH 5\% (Merck), H2SO4 (Merck).

Alat yang digunakan meliputi peralatan gelas (pirex), mikropipet 100-1.000 $\mu \mathrm{L}$, toples kaca ukuran $500 \mathrm{~mL}, 2 \mathrm{~L}$, dan $10 \mathrm{~L}$, sentrifus, lampu TL40 watt (Hannoch), timer (24 Hour Time Switch Intra), spektrofotometer (Spectro UV-VIS 2500), aerator (AP 500), mikroskop cahaya (Olimpus), oven (Yamato DV 41) dan neraca (Sartorius TE214S), vortex, hot plate, otoklaf (Yamato SM 52), inkubator, oven (Yamato SH 62), furnace, desikator, ruang laminar, waterbath, spektrometer UV/VIS Perkin Elmer (Yamato), pH meter (Thermo), dan UFLC (Shimadzu).

\section{Metode Penelitian}

Penelitian ini dilakukan dalam tiga tahap, yaitu 1) kultivasi mikroalga, untuk menghasilkan biomasa dengan kandungan eksopolisakarida terbanyak; 2) pemanenan dan karakterisasi eksopolisakarida, untuk mendapatkan eksopolisakarida tertinggi menggunakan bahan presipitasi berbeda; 3) hidrolisis eksopolisakarida, untuk mendapatkan hidrolisat dengan kandungan gula tertinggi.

\section{Kultivasi Porphyridium cruentum}

Kultivasi dimulai dari tahap penyegaran kultur selama 7 hari dalam erlemenyer menggunakan media Guillard. Volume kultur untuk penyegaran adalah $500 \mathrm{~mL}$ dengan inokulum sebanyak 20\% (v/v). Penyegaran stok mikroalga dilakukan dalam keadaan aseptik pada suhu ruang menggunakan lampu neon dengan intensitas cahaya 2.000-2300 lux sebagai sumber cahaya, dan dilengkapi dengan aerasi terus-menerus. Tahap kultivasi diperbesar dengan menggunakan toples kaca kapasitas 2 L selama 7 hari, kemudian dilakukan scale up dari kultur $2 \mathrm{~L}$ menjadi 10 L selama 40 hari dengan perlakuan fotoperiod 12 : 12 jam (terang : gelap) (Prasetyo et al. 2016) dan dilakukan pengukuran kepadatan sel menggunakan spekrofotometer $\lambda 760$ serta penghitungan jumlah sel menggunakan haemositometer.

\section{Pemisahan Eksopolisakarida}

Pemisahan eksopolisakarida dilakukan dengan cara dipresipitasi menggunakan 2 bahan presipitasi berbeda. Kultur P. cruentum dipresipitasi menggunakan etanol $96 \%(1: 0,75 \mathrm{v} / \mathrm{v})$ (Setyaningsih et al. 2013) dan KOH 5\% (1:1,5 v/v) (Prasetyo et al. 2016). Eksopolisakarida disaring dan dikeringkan menggunakan oven pada suhu $50^{\circ} \mathrm{C}$ selama 12 jam. Eksopolisakarida kering dianalisis kadar air (AOAC 2007), kadar abu (BSN 1992), kadar gula total (Dubois et al. 1965), viskositas (Garesh 2002), rendemen, gugus fungsi (ASTM 2013), dan jenis monosakarida (Arad et al. 1985).

\section{Eksopolisakarida hidrolisis}

Proses hidrolisis eksopolisakarida menggunakkan 2 bahan penghidrolisis berbeda, yaitu $\mathrm{HCl} 2 \mathrm{~N}$ dan akuades (Patel et al. 2013). Eksopolisakarida sebanyak $1 \mathrm{mg}$ ditambahkan $10 \mathrm{~mL}$ asam, kemudian dipanaskan pada suhu $100^{\circ} \mathrm{C}$ selama 3 jam. Hidrolisat eksopolisakarida dianalisis kandungan gula total menggunakan metode fenol sulfat, bertujuan untuk mengetahui kemampuan masing-masing asam dalam menghidrolisis substrat.

\section{Pengukuran viskositas}

Eksopolisakarida dilarutkan dalam akuades dengan konsentrasi 0,25\% $(\mathrm{b} / \mathrm{v})$, kemudian diaduk menggunakan magnetic stirrer plus heater dengan suhu $50^{\circ} \mathrm{C}$ selama 30 menit hingga larutan homogen. Viskositas diukur menggunakan viskometer Toki Sangyo TV-10 dengan spindle M2 no 18 pada kecepatan $50 \mathrm{rpm}$ (modifikasi Geresh et al. 2002). Nilai viskositas yang terukur dinyatakan dalam satuan $\mathrm{cP}$ (Centipoise).

\section{Penentuan kandungan gula total metode fenol sulfat}

Penentuan gula total didasarkan pada metode fenol sulfat (Dubois et al. 1956), sebelum melakukan pengujian sampel maka perlu diketahui kurva standar fenol yang digunakan. Kurva standar fenol disiapkan dengan melarutkan $2 \mathrm{~mL}$ larutan glukosa standar pada konsentrasi $0,10,20,30,40,50$ 
dan $60 \mathrm{mg} / \mathrm{L}$. Larutan glukosa dimasukkan ke dalam tabung reaksi dan ditambahkan $1 \mathrm{~mL}$ larutan fenol 5\%, kemudian dikocok. Asam sulfat $\left(\mathrm{H}_{2} \mathrm{SO}_{4}\right)$ pekat sebanyak $5 \mathrm{~mL}$ ditambahkan dengan cepat, dibiarkan selama 10 menit, kemudian dikocok lalu tempatkan dalam penangas air selama 15 menit. Pengukuran absorban dilakukan pada panjang gelombang $490 \mathrm{~nm}$ dengan menggunakan spektrofotometer. Tahapan yang dilakukan pada pengujian sampel sama dengan pembuatan kurva standar fenol, dengan cara menggantikan $2 \mathrm{~mL}$ larutan glukosa dengan 2 mL sampel.

\section{Analisis gugus fungsi}

Gugus fungsi dari eksopolisakarida dideteksi dengan Fourier Transformed Infrared (FTIR) mengacu pada (Mishra dan Jha 2009). Pelet untuk analisis FTIR diperoleh dengan memasukkan $200 \mathrm{mg}$ Kbr dan2 mg sampel ke dalam mortar serta dicampurkan sampai homogen. Sampel dipadatkan dan dimasukkan ke dalam Tensor 37. Pengukuran sampel uji dilakukan pada bilangan gelombang antara 4.000-500 $\mathrm{cm}^{-1}$. Spektra FTIR yang dihasilkan menunjukkan puncak-puncak serapan bilangan gelombang dari sampel uji. Gugus-gugus fungsi sampel uji ditentukan berdasarkan puncak serapan bilangan gelombang yang terdeteksi.

\section{Analisis monosakarida}

Analisis monosakarida mengacu pada Patel et al. (2013) yang dimodifikasi. Eksopolisakarida 0,1 g dihidrolisis dengan 2 $\mathrm{N}$ HCl10 mL selama 3 jam pada suhu $100^{\circ} \mathrm{C}$.
Hidrolisat eksopolisakarida dinetralkan dengan $\mathrm{NaOH} 2 \mathrm{~N}$ dan difiltrasi menggunakan sartorius single use filter unit dengan ukuran $0,45 \mathrm{~nm}$. Komposisi monosakarida ditentukan dengan Ultra Fast Liquid Cromatography (UFLC). Area puncak diperkirakan sebagai komposisi monomer.

\section{Analisis struktur partikel}

Analisis struktur partikel eksopoliskarida $P$. cruentum menggunakan metode Scanning Electron Microscopy (SEM). Sampel sebanyak $0,2 \mathrm{~g}$ disebar pada piringan metalsilinder dengan pita karbon dan dilapisi dengan emas dibawah vakum. Karakterisasi mikrograf dilakukan dengan menggunakan instrumen Scanning Electron Microscopy (SEM) yang dioperasikan pada $14 \mathrm{kV}$ tegangan percepatan.

\section{HASIL DAN PEMBAHASAN \\ Karakteristik $\boldsymbol{P}$ cruentum}

Porphyridium cruentum yang dikultur pada media Guillard dipanen pada umur 40 hari memiliki nilai $\mathrm{pH} 7,27$, dengan nilai OD 0,935. Djemai-Zoghlache et al. (2011) melaporkan kepadatan sel Porphyridium purpureum yang dikultivasi dengan fotoperiode 12:12 jam mencapai nilai OD hingga 1 pada umur 40 hari. Hasil penelitian menunjukkan bahwa sel P. cruentum berwarna merah terang. Kusmiyati dan Agustini (2006) menyatakan bahwa warna merah terang pada P.cruentum disebabkan oleh keberadaan fikoeritrin sebagai pigmen yang dominan. Sel berbentuk bulat dengan diameter mencapai $5,16 \mu \mathrm{m}$ (Gambar 1), hasil ini identik seperti

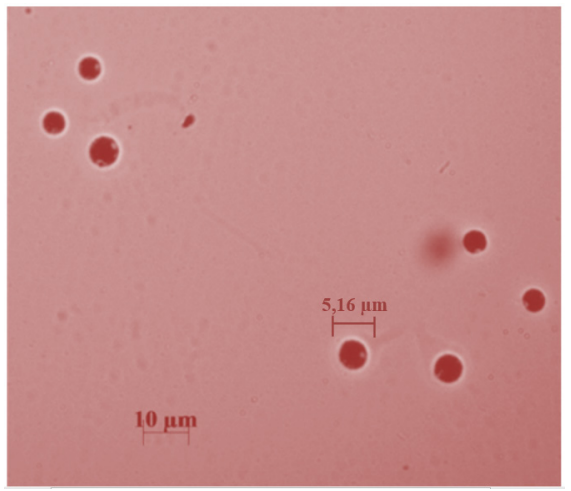

Gambar 1 P. cruentum hari ke-40 kultur

(Figure 1 Cells of P. cruentum at day 40) 
yang dilaporkan oleh Prasetyo et al. (2016).

Nilai viskositas media kultivasi pada umur 40 hari adalah 7,83 cp. Hasanah (2016) melaporkan bahwa nilai viskositas P.cruentum pada umur 40 hari sebesar 7,97 cp. Arad dan Levy-Ontman (2010) menyatakan bahwa nilai viskositas sangat dipengaruhi oleh jumlah eksopolisakarida yang dilepaskan ke medium, semakin banyak jumlah polisakarida yang dikeluarkan ke dalam medium, maka akan menghasilkan viskositas yang lebih tinggi, karena pembungkus dinding sel mikroalga merah merupakan polisakarida sulfat yang membentuk gel, polisakarida sulfat tersebut akan dikeluarkan ke dalam medium selama pertumbuhannya.

\section{Karakteristik Eksopolisakarida $P$. cruentum

Rendemen, kadar abu dan kadar air eksopolisakarida kering dapat dilihat pada (Tabel 1). Bahan presipitasi memengaruhi rendemen eksopolisakarida yang dihasilkan. Presipitasi dengan $\mathrm{KOH}$ 5\% menghasilkan rendemen 4 kali lebih tinggi dibandingkan dengan etanol $96 \%$.
Zulfriady dan Sudjatmiko (1995) melaporkan bahwa penggunaan $\mathrm{KOH}$ berpengaruh terhadap kenaikan rendemen dan mutu karaginan yang dihasilkan. Rendemen yang dihasilkan lebih tinggi dari hasil penelitian Prasetyo et al. (2016). Eksopolisakarida yang diproduksi oleh sel $P$. cruentum dipengaruhi faktor pertumbuhan dan lingkungan. Singh et al. (2000) menyatakan bahwa $P$. cruentum yang ditumbuhkan pada musim dingin akan memproduksi polisakarida berkisar 200 hingga $1.000 \mathrm{mg} / \mathrm{L}$.

Perlakuan penambahan alkali mampu meningkatkan ekstraksi polisakarida menjadi sempurna (Mustamin 2012). Kemampuan gugus $\mathrm{H}+$ dari alkali yang bereaksi dengan gugus $\mathrm{OH}-$ eksopolisakarida membentuk polimer anhydrous galaktosa sehingga menghasilkan eksopolisakarida lebih banyak (Uy et al. 2005). Hal ini sesuai dengan pernyataan (Ega et al. 2016) bahwa perlakuan penambahan konsentrasi $\mathrm{KOH}$ berpengaruh nyata terhadap kadar karbohidrat rumput laut Euchema cottonni. Hasil eksopolisakarida kering dengan ekstraksi menggunakan $\mathrm{KOH} 5 \%$ dan etanol $96 \%$ dapat dilihat pada Gambar 2.

Tabel 1 Kadar Air, abu dan rendemen eksopolisakarida kering P.Cruentum (Table 1 Moisture, ash and yield of P. Cruentum exopolysaccharide)

\begin{tabular}{ccc}
\hline \multirow{2}{*}{ Parameter } & \multicolumn{2}{c}{ Bahan precipitation/Precipitation materials } \\
\cline { 2 - 3 } & KOH 5\% & Ethanol 96\% \\
\hline Kadar air/Moisture (\%) & $5.28 \pm 0.28$ & $12.70 \pm 1.02$ \\
Kadar abu/Ash (\%) & $78.67 \pm 1.19$ & $59.68 \pm 0.93$ \\
Rendemen/Yield (g/L) & $6.10 \pm 0.24$ & $1.40 \pm 0.06$ \\
\hline
\end{tabular}

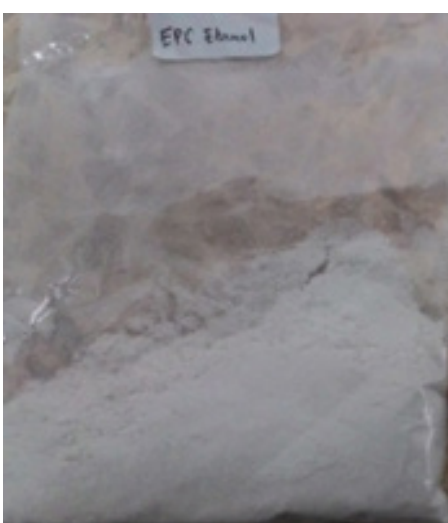

(a)

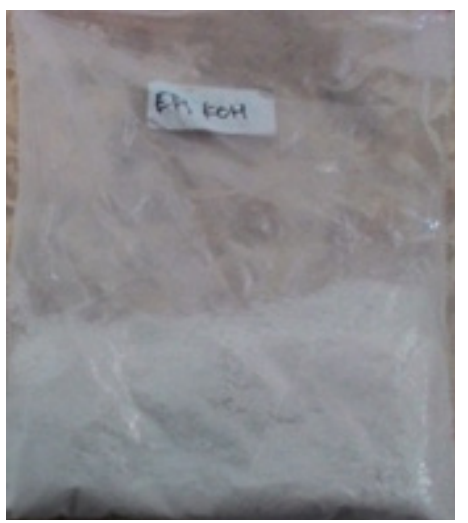

(b)

Gambar 2 Eksopolisakarida kering presipitasi etanol (a) dan presipitasi $\mathrm{KOH}$ (b). (Figure 2 Dried exopolysaccharides with ethanol precipitation (a) and $\mathrm{KOH}$ precipitation (b)) 
Kadar abu mengindikasikan adanya kandungan mineral pada bahan. Kadar abu pada eksopolisakarida P. cruentum adalah sebesar $78,67 \%$ (presipitasi dengan $\mathrm{KOH} 5 \%$ ) dan 59,68\% (presipitasi dengan etanol 96\%), hasil ini cenderung lebih tinggi dibandingkan dengan mikroalga air laut lainnya. Setthamongkol et al. (2015) melaporkan bahwa Caulerpa lentifiliera yang ditumbuhkan pada media F/2 dan dipanen dengan pencucian air tawar memiliki kadar abu yang lebih rendah yaitu sebesar $47,80 \%$.

P. cruentum dikultivasi menggunakan air laut yang diikuti dengan penambahan mineral tertentu, hal ini menyebabkan salinitas menjadi tinggi. Hal ini didukung dengan pernyataan Selco et al. (2003) bahwa air laut mengandung berbagai komponen mineral diantaranya $\mathrm{Na}^{+}, \mathrm{K}^{+}, \mathrm{Mg}^{2+}, \mathrm{Ca}^{2+}, \mathrm{Cl}^{-},\left(\mathrm{SO}_{4}^{2-}\right)$, dan $\mathrm{Br}^{-}$.

Kadar air dalam bahan menunjukkan hasil yang berbeda antara eksopolisakarida presipitasi dengan $\mathrm{KOH} 5 \%$ dan etanol
96\%. Presipitasi dengan $\mathrm{KOH}$ terdeteksi memiliki kadar air lebih sedikit dibandingkan presipitasi dengan etanol (Tabel 1). Hal ini disebabkan oleh $\mathrm{KOH}$ memiliki sifat higroskopi dan eksotermik, yaitu mampu mengeluarkan panas, sehingga menyebabkan air lebih banyak menguap (Romenda et al. 2013). Kadar air presipitasi dengan etanol 96\% identik dengan hasil penelitian Hasanah (2016) yang melaporkan bahwa kadar air eksopolisakarida presipitasi dengan etanol $96 \%$ adalah sebesar 13,83 hingga 14,68 \%.

\section{Struktur partikel eksopolisakarida}

Hasil mikrograf eksopolisakarida P. cruentum menunjukkan bahwa permukaan pada masing-masing bahan pada perbesaran $100 \mathrm{x}$ dan 350x memiliki perbedaan (Gambar 3). Eksopolisakarida hasil presipitasi menggunakan etanol $96 \%$ memiliki kenampakan yang berbentuk batang, berbeda dengan eksopolisakarida hasil presipitasi dengan $\mathrm{KOH} \quad 5 \%$
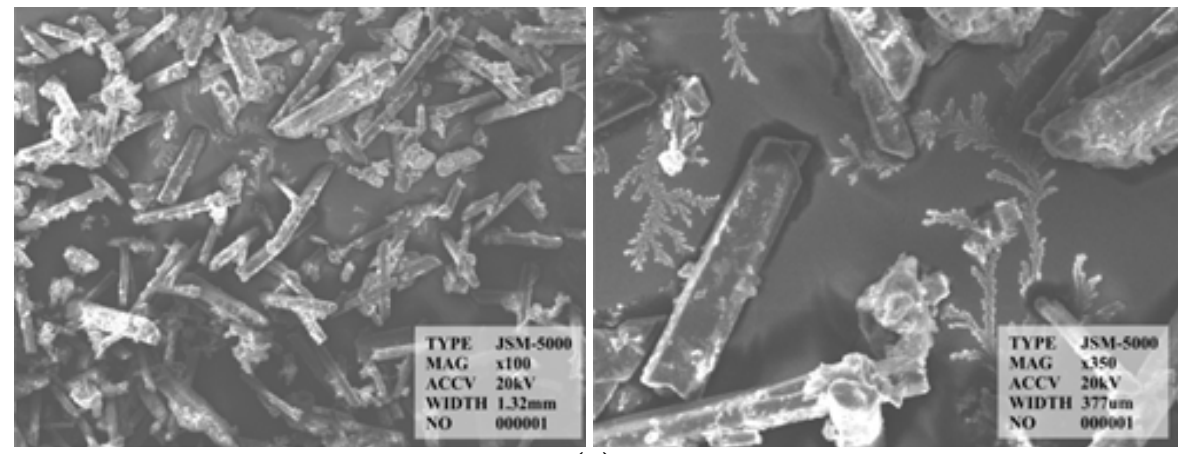

(a)

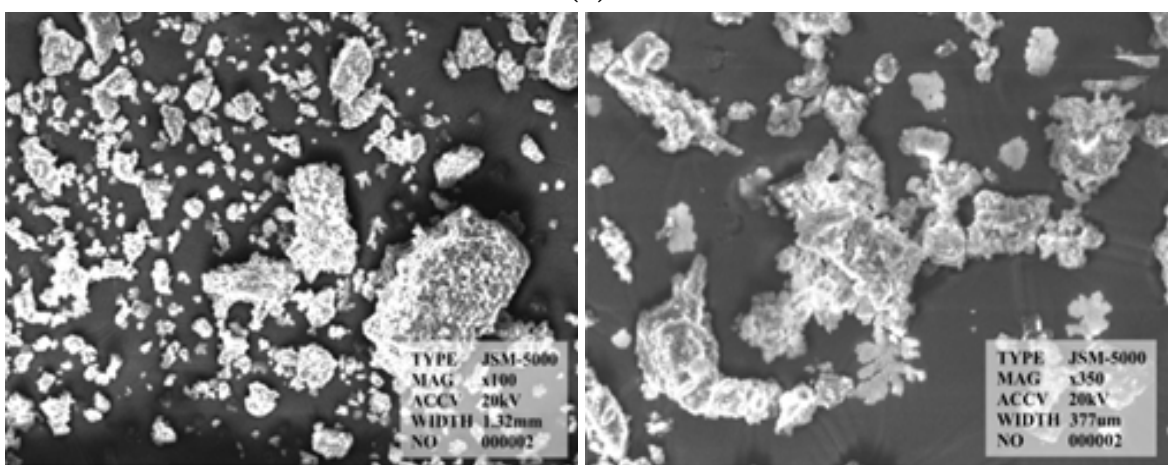

(b)

Gambar 3 Struktur partikel eksopolisakarida P. cruentum presipitasi dengan etanol 96\% (a) dan $\mathrm{KOH} 5 \%$ (b).

(Figure 3 Structure of P. cruentum exopolysaccharide after precipitation with $96 \%$ ethanol (a) and $\mathrm{KOH} \mathrm{5 \% (b))}$ 


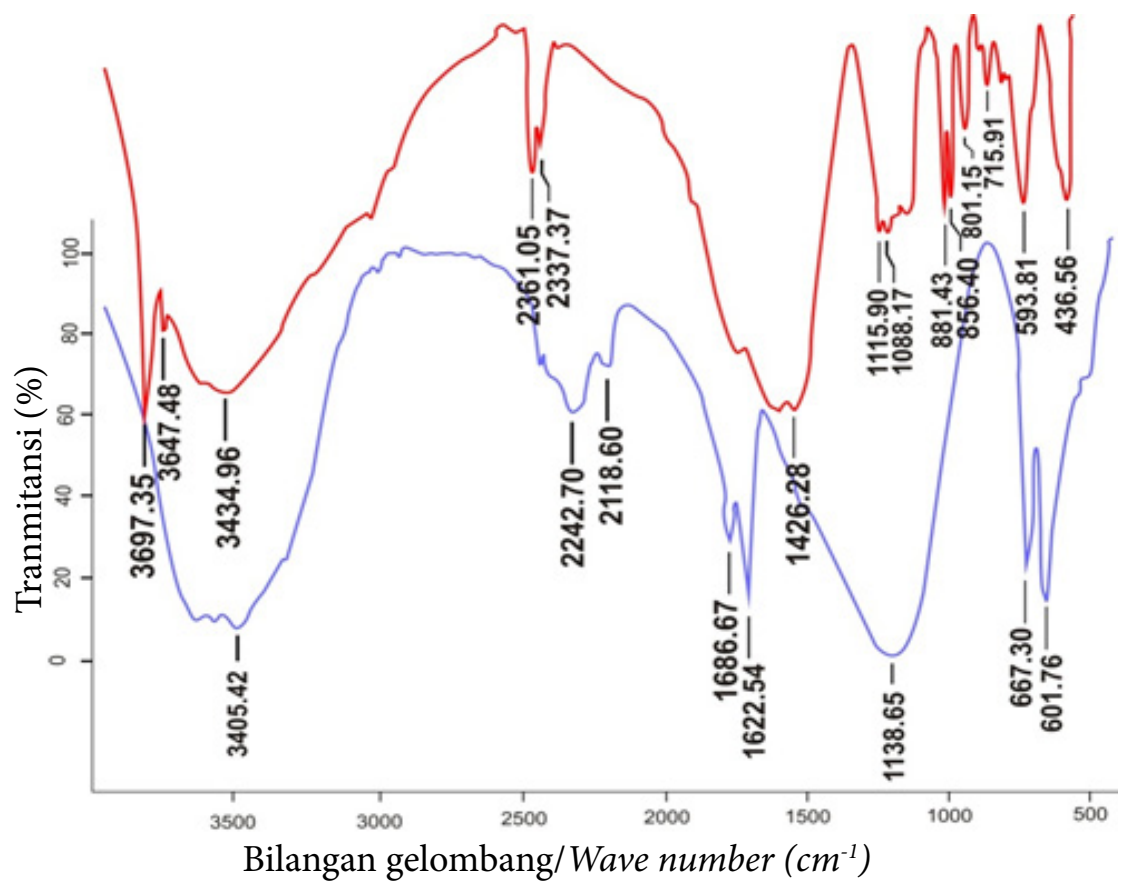

Gambar 4 Spektrum IR eksopolisakarida P. cruentum yang dipresipitasi dengan $\mathrm{KOH}$ 5\% (a) dan etanol 96\% (b).

Figure 4 IR spectrum of precipitated P. cruentum exopolysaccharide with $\mathrm{KOH} 5 \%$ (a) and ethanol 96\% (b).

yang sebagian besar memiliki ukuran lebih kecil dan lebih halus.

Filamen pada hasil SEM eksopolisakarida hasil presipitasi dengan etanol $96 \%$ diduga sebagai campuran membran sitoplasma yang menyatu dengan dinding sel eksopolisakarida. Hal ini sesuai dengan pernyataan Juin et al. (2014) bahwa adanya perubahan pada morfologi sel $P$. cruentum sehingga berbentuk filamen tipis panjang,termasuk fusi sistematik dari dinding sel, yang disebabkan bercampurnya membran sitoplasma dengan dinding sel eksopoliskarida.

\section{Gugus fungsi}

Gugus fungsi eksopolisakarida dari P. cruentum ditunjukkan dengan adanya puncak pita pada spektrum transmitan pada suatu bilangan gelombang, spektrum FTIR eksopolisakarida $P$. cruentum dapat dilihat pada Gambar 4.

$$
\text { Gugus } \quad \mathrm{O}-\mathrm{H} \quad \text { eksopolisakarida }
$$

P. cruentum terdeteksi pada $3647,48 \mathrm{~cm}^{-1}$ untuk KOH dan $3405,42 \mathrm{~cm}^{-1}$ untuk etanol. Hal ini sesuai dengan penelitian Abdala-Diaz et al. (2010) yang menyatakan bahwa gugus fungsi hidroksi $(\mathrm{O}-\mathrm{H})$ dari eksopolisakarida $P$. cruentum berada pada $3384 \mathrm{~cm}^{-1}$. Serapan yang muncul pada daerah bilangan gelombang 3697,3 dan 3622,1 menunjukkan adanya vibrasi ulur dari $-\mathrm{OH}$, sedangkan vibrasi pada 3431,1 $\mathrm{cm}^{-1}$ merupakan vibrasi $\mathrm{H}-\mathrm{O}-\mathrm{H}$ yang membentuk ikatan hidrogen dengan air. Hal ini juga ditegaskan oleh Madejova (2003) bahwa munculnya puncak pada bilangan gelombang 3669; 3653 dan $3620 \mathrm{~cm}^{-1}$ merupakan vibrasi ulur $-\mathrm{OH}$ dari silanol atau yang terdapat diantara lembaran tetrahedral dengan oktahedral. Katti (2001) melaporkan serapan pada $3634 \mathrm{~cm}^{-1}$ adalah vibrasi tekuk $\mathrm{O}-\mathrm{H}$ sedangkan pada bilangan gelombang $3433 \mathrm{~cm}^{-1}$ merupakan vibrasi $\mathrm{HO}-\mathrm{H}$ yang membentuk ikatan hidrogen dengan air.

Hasil analisis gugus fungsi $P$. cruentum menunjukkan adanya polisakarida, baik hasil presipitasi $\mathrm{KOH}$ maupun etanol, hal ini ditunjukkan dengan adanya penyerapan pada bilangan gelombang 1115,90 $\mathrm{cm}^{-1}$ pada $\mathrm{KOH}$ dan $1138,65 \mathrm{~cm}^{-1}$ pada etanol (Tabel 2). Penyerapan 1200-800 $\mathrm{cm}^{-1}$ menunjukkan adanya ikatan polisakarida dengan komposisi dan struktur yang berbeda (Sood et al. 2013). 
Tabel 2 Bilangan gelombang dan gugus fungsi eksopolisakarida P.cruentum dipresipitasi dengan bahan presipitasi berbeda

(Table 2 The wave numbers and funtional groups of P. cruentum exopolysaccharide after precipitated with different precipitation agents)

\begin{tabular}{ccccc}
\hline \multirow{2}{*}{$\begin{array}{c}\text { Wave numbers } \\
\left(\mathrm{cm}^{-1}\right)\end{array}$} & $\begin{array}{c}\text { Functional } \\
\text { groups }\end{array}$ & \multicolumn{2}{c}{ Wave numbers $\left(\mathrm{cm}^{-1}\right)$} & \multirow{2}{*}{ Compound } \\
\cline { 3 - 4 } & $\mathrm{O}-\mathrm{H}$ & 3647.48 & 3405.42 & Hydroxyl \\
\hline $3660-2990$ & $\mathrm{C}=\mathrm{O}$ & 1426.28 & 1686.67 & Ketones \\
$1740-1610$ & $\mathrm{C}-\mathrm{H}$ & 1115.90 & 1138.65 & Polysccharides \\
$1330-1190$ & & & & \\
\hline
\end{tabular}

Senyawa-senyawa lain juga terlihat pada hasil analisa gugus fungsi, diantaranya senyawa sulfida pada bilangan gelombang 2361,05-2337,37 untuk eksopolisakarida hasil presipitasi dengan $\mathrm{KOH} 5 \%$ dan 2242,70-2118,60 pada eksopolisakarida hasil presipitasi dengan etanol $96 \%$, hal ini sesuai dengan pernyataan Patel et al. (2013) yang melaporkan bahwa eksopolisakarida $P$. cruentum memiliki kandungan sulfat sebanyak $0,082 \mathrm{~g} / \mathrm{g}$. Senyawa lainnya yang terdeteksi adalah senyawa golongan $\mathrm{O}-\mathrm{H}$, dalam hal ini adalah senyawa $\mathrm{KOH}$ atau EtOH (etanol) yang digunakan sebagai bahan untuk presipitasi eksopolisakarida. Senyawa golongan $\mathrm{C}-\mathrm{Cl}$ juga terdeteksi yaitu senyawa garam pada media air laut yang digunakan.

\section{Viskositas eksopolisakarida}

Presipitasi dengan etanol menghasilkan viskositas eksopolisakarida yang lebih tinggi dibanding dengan presipitasi KOH. Nilai viskositas eksopolisakarida $P$. cruentum pada konsentrasi $0,25 \%$ cukup tinggi yaitu sebesar $76,8 \mathrm{cP}$ (presipitasi dengan $\mathrm{KOH}$ ) dan 134,4 cP (presipitasi etanol 96\%). Nilai viskositas semakin besar maka semakin besar kekentalan larutan. Jading et al. (2011) menyatakan bahwa nilai viskositas pati dipengaruhi oleh daya serap air, suhu dan $\mathrm{pH}$. Suhu pengeringan oven yang tinggi dan perubahan $\mathrm{pH}$ pada presipitasi $\mathrm{KOH}$ diduga memengaruhi viskositas eksopolisakarida yang dihasilkan. Ginzberg et al. (2008) melaporkan viskositas eksopolisakarida P. cruentum pada konsentrasi $0,5 \%$ mencapai $1.000 \mathrm{cP}$. Bahan presipitasi yang berbeda diduga berpengaruh terhadap viskositas eksopolisakarida.

\section{Jenis monosakarida}

Monosakarida yang terdeteksi pada eksopolisakarida hasil presipitasi $\mathrm{KOH}$ maupun etanol adalah fruktosa, pada waktu retensi menit ke 9,0-10,0, dengan jumlah sebanyak 18,3 g/L (presipitasi $\mathrm{KOH}$ ) dan 18,9 g/L (presipitasi etanol 96\%). Waktu retensi menit ke 3,5-5,0 merupakan pelarut yang digunakan yaitu air (kontrol) (Gambar 5). Menurut Markou et al. (2013) fruktosa merupakan isomer dari glukosa yang dapat difermentasi menjadi bioetanol. Bai et al. (2008) melaporkan bahwa pada jalur metabolisme fermentasi oleh S. cerevisiae, fruktosa termasuk jenis gula yang bisa difermentasi oleh $S$. cerevisiae menjadi bioetanol (Gambar 5).

Hasil ini berbeda dengan penelitian Patel et al. (2013) yang menyatakan bahwa eksopolisakarida $P$. cruentum mengandung galaktosa $40 \%$, xilosa $30 \%$, glukosa $20 \%$, dan asamglukoroniksebesar 10\%.Eksopolisakarida P. cruentum terdiri dari polisakarida tunggal dengan diversitas yang sangat besar, maka eksopolisakarida $P$. cruentum memiliki potensi kandungan monosakarida hasil degradasi dari polisakarida yang beragam. Hasanah (2016) melaporkan bahwakandungan gula eksopolisakarida $P$. cruentum yang terdeteksi adalah maltoheptosa, maltoheptosa merupakan tujuh disakarida maltosa yang tersusun dari komponen glukosa.

\section{Kadar gula total hidrolisat eksopolisakarida}

Kadar gula total dari esopolisakarida dengan presipitasi etanol 96\% dan $\mathrm{KOH}$ 5\% menggunakan bahan penghidrolisis $\mathrm{HCl}$ 


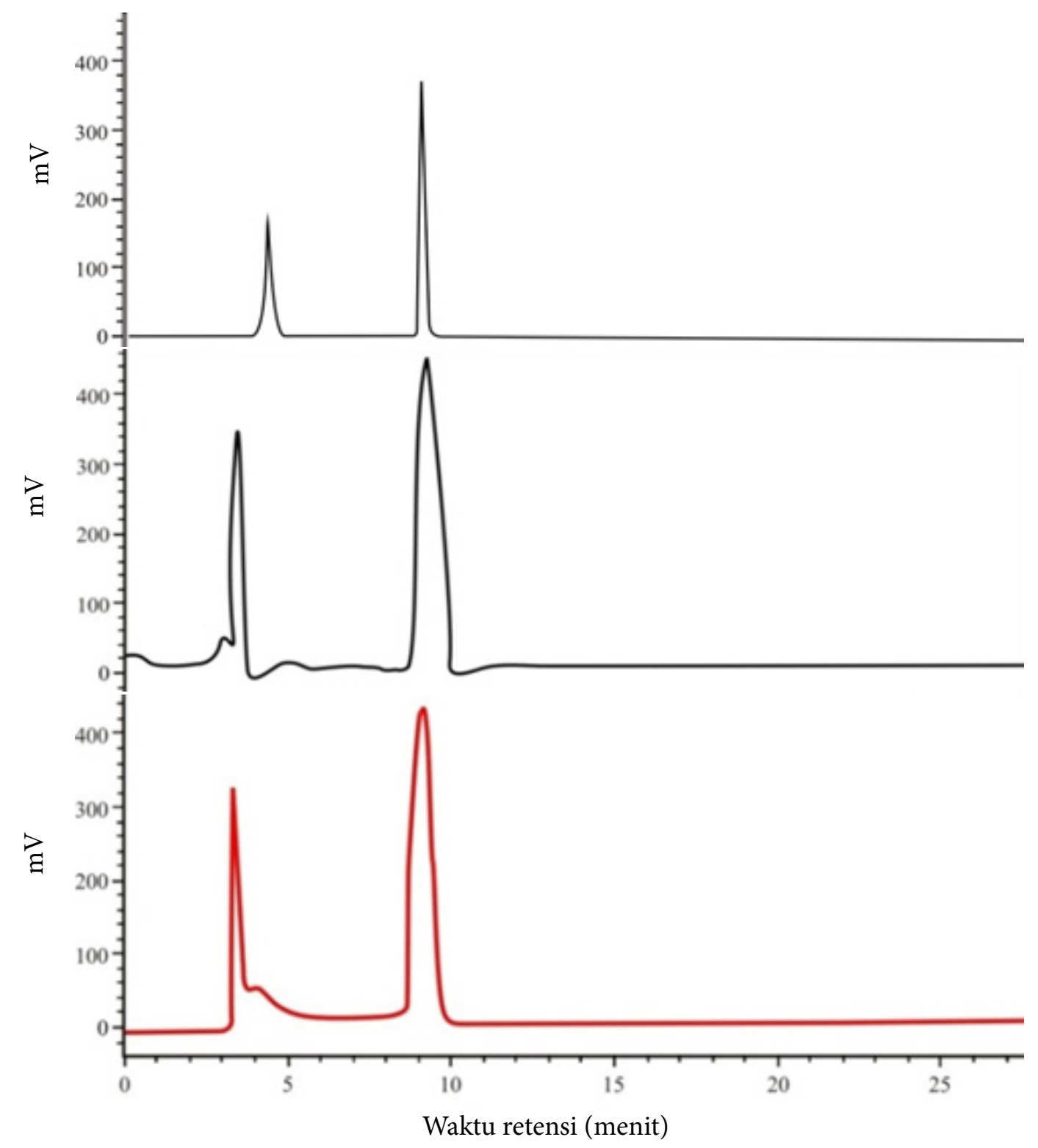

Gambar 5 Monosakarida eksopolisakarida hasil presipitasi dengan $\mathrm{KOH}$ 5\% (a) presipitasi dengan etanol 96\% (b), dan standar (c)

(Figure 5 Monosaccharide of exopolysaccharide precipitated with $\mathrm{KOH} 5 \%$ (a) 96\% ethanol (b), and standard (c))

$2 \mathrm{~N}$ yaitu $24,81 \pm 1,07 \%$ dan $22,56 \pm 1,77 \%$, sedangkan menggunakan akuades sebagai penghidrolisis yaitu $12,80 \pm 0,16$ dan $9,43 \pm 1,61$. Kadar gula tertinggi dari eksopolisakarida dengan presipitasi etanol $96 \%$ diperoleh dari hidrolisis $\mathrm{HCl} 2 \mathrm{~N}$. Menurut Iryani (2013) asam klorida efektif memecah molekul pati dan mampu menghasilkan sakarida berantai pendek. Penambahan $\mathrm{HCl}$ menyebabkan nilai konstanta reaksi hidrolisis terhadap konversi pati lebih cepat yaitu 0,0086/menit dengan konversi sebesar 0,2884. Bailar et al. (1965) menyatakan bahwa larutan $\mathrm{HCl}$ memiliki reaktivitas lebih tinggi, sehingga menyebabkan lebih banyak polisakarida terdegradasi, hal ini umumnya ditandai dengan warna yang lebih pekat.

\section{KESIMPULAN}

Eksopolisakarida hasil presipitasi etanol dan $\mathrm{KOH}$ memiliki perbedaan karakteristik pada hasil analisis kadar air, abu, struktur 
partikel, viskositas, dan gugus fungsi, namun jenis monosakarida yang terdeteksi sama, yaitu fruktosa, yang bisa dimanfaatkan oleh kapang untuk proses fermentasi menjadi etanol. Hidrolisis terpilih adalah menggunakan $\mathrm{HCl}$ $2 \mathrm{~N}, 100^{\circ} \mathrm{C}$, selama 3 jam dengan kadar gula total yang dihasilkan sebesar $24,31 \%$.

Presipitasi dengan $\mathrm{KOH}$ menghasilkan rendemen eksopolisakarida kering 4 kali lebih tinggi daripada presipitasi dengan etanol, sehingga $\mathrm{KOH}$ bisa menjadi alternatif bahan presipitan pada pemanenan eksopoliskarida P. cruentum.

\section{DAFTAR PUSTAKA}

[AOAC] Association of Official Analytical Chemist. 2007.Official of Analysis of the Association of Official Analytical of Chemist. Arlington (USA). The Association of Official Analytical of Chemist, Inc.

Arad SM, Adda M, Cohen E. 1985. The potential of production of sulfated polysaccharides from Porphyridium. Plant and Soil. 89: 117-127.

Arad S, Levy-Ontman O. 2010. Red microalgal cell-wall polysaccharides: biotechnological aspect. Current Opinion in Biotechnology. 21: 358-364.

[ASTM] American Society for Testing Material. 2013. ASTM E1252 : Standard Peactice for General Techniques for Obtaining Infrared Spectra for Qualitative Analysis. Pennsylvania (US): American Society for Testing Material.

Bai FW, Anderson WA, Moo-Young M. 2008. Ethanol fermentation technologies from sugar and starch feedstocks. Biotechnology Advances. 26: 89-105.

Dubois M, Gilles KA, Hamilton JK, Rebers PA, Smith F. 1956. Colorimetric method for determination of sugars and related substances. Analitic Chemical. 28: 350356.

Ega L, Lopulalan CGC, Meiyasa F. 2016. Kajian mutu karaginan rumput laut Euchema cottonii berdasarkan sifat fisiko kimia pada tingkat konsentrasi kalium hidroksida yang berbeda. Jurnal Aplikasi Teknologi Pangan. 5 (2) : 38-44.

Geresh S, Mamontov A, Weinstein J. 2002.
Sulfation of extracellular polysaccharides of red microalgae: preparation, characterization and properties. Journal Biochemichal Biophyscal Methods 50: 179187

Hasanah, Setyaningsih I, Uju. 2016. Teknik pemanenan dan pemisahan polisakarida Porphyridium cruentum dengan membran ultrafiltrasi. Jurnal Pengolahan Hasil Perikanan Indonesia. 19 (2): 110120.

Iryani AS. 2013. Pengaruh jenis katalis asam terhadap studi kinetika proses hidrolisis pati dlam ubi kayu. Ilmu Teknik. 8(15): 1078-1081.

Jading A, Tethool E, Payung P, Gultom S. 2011. Karakteristik fisikokimia pati sagu hasil pengeringan secara fluidisasi menggunakan alat pengering cross flow fluidized bed bertenaga surya dan biomassa. Reaktor. 3(13): 155-164.

Juin C, Cherouvrier JR, Thiery V, Gagez AL, Berard JB, Joguet $\mathrm{N}$, Kaas $\mathrm{R}$, Cadoret JP, Picot L. 2014. MicrowaveAssisted extraction of phycobiliproteins from Porphyridium purpureum. Appied Biochemical Biotechnology. 175: $1-15$.

Katti K, Katti D.Effect of clay-waterinteractions on swelling in montmorillonite clay. 2001. Departement of Civil Engineering and Construction North Dakota State University, Fargo.

[KESDM] Kementerian Energi dan Sumber Daya Mineral. 2015. Renstra Kementerian ESDM tahun 2015-2019. Jakarta (ID): KESDM.

Kusmiati, Agustini SNW. 2010. Manfaat eksopolisakarida dari mikroalga Porphyridium cruentum sebagai obat luka terbuka. Prosiding Seminar Nasional Rumput Laut dan Minisimposium Mikroalgae II. Jakarta. 22-21 Juni 2010: hal. 261-271-ISBN 979-8105-87-7.

Madejova J. 2003. FTIR techniques in clays mineral studies. Slovac Academy of Sciences. 31. 1 - 10.

Markou G, Angelidaki I, Nerantzis E, Georgakakis D. 2013. Bioethanol production by carbohydrate-Enriched biomass of Arthrospira (spirulina) 
platensis. Energies. 6: 3937-3950.

Mishra A, Jha B. 2009. Isolation and characterization of extracellular polymeric substances from microalgae Dunaliella salina under salt stress. Bioresource Technology. 100 : 3382-3386.

Patel AK, Laroche C, Marcati A, Ursu AV, Jubeau s, Marchal L, Petit E, Djelveh G, Michaud P. 2013. Separation and fractionation of exopolysaccharides from Porphyridium cruentum. Bioresources Technology. 145: 345-350.

Prasetyo H, Setyaningsih I, Agungpriyono DR. $2016 . \quad$ Pertumbuhan dan produksi eksopolisakarida Porphyridium cruentum pada berbagai kondisi fotoperiode. Jurnal Pengolahan Hasil Perikanan Indonesia. 18 (2): 220-230.

Romenda AP, Pramesti R, Susanto AB. 2013. Pengaruh perbedaan jenis dan konsentrasi larutan alkali terhadap kekuatan gel dan viskositas karaginan Kappaphycus alverezii, Doty. Journal of Marine Research. 2(1): 127-133.

Selco JI, Roberts JL, Jr Wacks DB. 2003. The analysis of seawater: a laboratory - centered learning project in general chemistry. Journal of Chemical Education 80 (1): 54-57.

Setthamongkol P, TunkijjanukijS, Satapornanit K, Salaenol J. 2015. Growth and nutrient analysis in marine macroalgae. Kasetsart
Journal. 49:211-218.

Setyaningsih I, Salamah E, Rahman DA. 2013. Komposisi kimia dan aktivitas antihiperglikemik biomassa dan polisakarida ekstraseluler dari mikroalga Porphyridium cruentum. Jurnal Pengolahan Hasil Perikanan Indonesia.16 (1): 79-85.

Singh S, Arad SA, Richmond A. 2000. Extracellular polysaccharide production in outdoor mass cultures of Porphyridium sp. in flat plate glass reactors. Journal ofApplied Phycology. 12: 269-275.

Sood G, Sharma S, Kapoor S, Khanna PK. 2013. Optimization of extraction and characterization of polysaccharides from medicinal mushroom Ganoderma lucidum using response surface methodology. Journal Medical Plants. 7 (31): 2323-2329.

Spolaore P, Joannis-Cassan C, Duran E, Isambert A. 2006. Commercial applications of microalgae. Journal of Bioscience Bioengineering. 101:87-96.

Uy FS, Easteal AJ, Fard MM. 2005. Seaweed processing using industrial singlemode cavity microwave heating: a preliminary investigation. Carbohydrate Research. 340: 1357-1364. 